\title{
Coastal and marine tourism: the employment system in Northern Latium at the time of the economic crisis
}

Gerardo Gallo The ending of the global economic crisis has Italian National Institute left some sectors of the economy in the need of Statistics (Istat), Italy to start-off with a more efficient and more E-mail: gegallo@istat.it competitive offer of the pre-crisis period.

Armando Montanari Rome offers urban and cultural tourism that presents problems of over-crowding and risk Sapienza University of Rome, Italy of banalisation of the product. Thus, owing to
E-mail: all the tourism, Rome managed to overcome Armando.montanari@uniroma1.it the crisis period without much difficulty. However, the situation on the coast near Rome is still problematic. It extends along the sea between the Fiumicino Airport and the port of Civitavecchia. Coastal and marine tourism products have undergone major transformations, and to overcome the crisis, a profound renewal work is required. There is a need for a different regional development organisation to update supply and offer new products to guests. Up until now, coastal entrepreneurs had only considered their territory and their business. A possible solution to the problem is suggested by greater integration between the coast and inland areas. In the case of Lazio, these areas are rich in tangible cultural goods, as a result of various civilizations that developed over the centuries, and intangible cultural goods that are the result of sedimentation of different cultures. The situation of coastal and marine tourism on the north coast of Lazio is considered in relation to the development of the sector in the rest of Italy. The variables under consideration are those of the tourism sector in the period 2001-2011 to check the effects of the global economic crisis on employment at each individual municipali-

Regional Statistics, Vol. 7. No. 2. 2017: 35-57; DOI: 10.15196/RS070204 
ty. The analysis examines all municipalities in order to confirm how the crisis has had consequences, particularly on the coastal communes. Only the communes of the coast are taken into consideration. The indexation of occupants in tourism in comparison to the residents shows a clear difference between the municipalities in northern Italy and those in southern Italy. However, the study of the employment situation in the Latium region shows a lesser presence of occupiers in the coastal areas where the supply is potentially concentrated. In the seven communes of the North Coast, the situation is even more wor-

Keywords: rying, as it is clear that many of the activities

tourism, are carried out by companies that are located employment, outside the area, as the ones inside are inaderegional development, quate and unable to compete at national and small and medium-sized international levels. Hence, there is a need to enterprises, create networks of companies where cooperaLatium tion and better organisation can enable them to be more competitive.

\section{Introduction}

The term 'seaside tourism' has long been used to refer to those forms of recreational and free-time activities that take place along the coast. In the Mediterranean, the coastal region is often a narrow area that includes land and sea. Seaside tourism developed in Western European countries since the end of World War II in conjunction with the Fordist production model, a general climate of strong economic development and the consolidation of the welfare state that provided appropriate paid holiday leave. This period of industrial production also promoted Fordist development in the tourism sector and domination by major tour operators, hotel chains, and airlines. The period also featured a prevalence of integration in various forms between the systems for accommodation, transport, and service management. The result was a phenomenon that has been termed 'mass tourism', concentrated mainly around the coasts of the regions that front onto the Mediterranean. The resulting product has been defined by the 'three S's' (sun, sand, and sea) as the focus of the demand is a product that has no connection to the environment, landscape, and culture of the place. Tourism demand at this stage was shown by the typical behaviours of what is called the 'modern tourist' (Claval 1995). Periods of

Regional Statistics, Vol. 7. No. 2. 2017: 35-57; DOI: 10.15196/RS070204 
economic crises have always been associated with the acceleration of the period of decline of already-mature products. The economic crisis that dogged Europe between 2007 and 2014 accelerated changes in habits and in the culture of demand. We are now in a transition period that is being used to understand how supply can be restructured to suit the tastes of tourists who now display the characteristics of post-modern consumers. During the years of the economic crisis, seaside tourism in Italy grew lesser than other types of tourism, mainly as consumers living in Italy generated a smaller share of tourism of this type. This phenomenon must also be considered in terms of the challenges that seaside tourism suffered in many nonEuropean Union (the EU) Mediterranean countries owing to war or terrorist attacks organised partly to create panic among foreign consumers of the seaside tourism industry. Therefore, traditional seaside tourism in Italy entered a recession, but the demand from Italian consumers has not decreased; instead, we have observed growth in the cruise sector, and seaside tourism in France and Spain has remained stable. This essay seeks to ascertain whether and how the decline in seaside tourism has affected tourism-related occupations in coastal Italian municipalities. The employment sectors we will consider are accommodation, transportation, and tourismrelated services.

This essay will not only discuss seaside tourism - the type of tourism that has for years been known by the 'three S's' - but also the wide range of options that coastal municipalities of Italy may offer, such as boat trips, marine protected areas, diving, and fishing (Hall 2001). In addition, we cannot ignore the fact that cruise tourism has grown steadily, even considering the economic crisis. Cruise passengers are considered tourists with high added value as, on an average, they spend more than other types of tourists (Dwyer-Forsyth 1998). Cruises in the Mediterranean basin are characterised by a varied supply of tourism products and services that we could call 'soft' as all those recreational and leisure opportunities that were previously available exclusively in coastal areas are offered on board. The difference between traditional coastal tourism and cruise tourism is not in the product offered, but in the integration of various elements of that product. In traditional coastal tourism, as in the case of the northern Latium coastal areas, there is almost no integration; the elements in cruise tourism are fully integrated. This different organisation is also reflected in price packaging. In traditional tourism, the cost of the holiday is the sum of the costs of each element. It is generally challenging to determine a priori and will always be subject to instability in terms of timing and options. In cruise tourism, the offer is organised in 'packages' that are clearly identified at the time of purchase. What the two modes have in common is the territory. Traditional tourism is firmly connected to the territory, albeit in a fragmented manner up to now. In cruise tourism, the territory is a distinguishing element in the product, which is why daily stops are made in ports connected with historic centres and areas with monuments.

Regional Statistics, Vol. 7. No. 2. 2017: 35-57; DOI: 10.15196/RS070204 
The essay examines employment data from 2001, long before the clues and signs of the international economic crisis, and from 2011, when the crisis had already been evident for some years and the various industries had already taken initial measures to mitigate its effects. The first chapter examines the international literature from recent decades on coastal tourism to draw attention to its changing characteristics, approach, and organisation. The second chapter presents the characteristics of Italian coastal tourism. The third chapter compares the specific features of Italian tourism to those of coastal tourism. The fourth chapter explores the issues of coastal tourism by examining a case study from the northern coast of Latium. The tourism crisis in this area highlights the need for restructuring into a sector that, in this specific case, is located in an area between the Leonardo da Vinci International Airport, the historic centre of Rome and the Port of Civitavecchia, where most Sardinia-bound passengers pass through. Civitavecchia is also Italy's main port for cruises. Passenger traffic at this port is comparable to that of to the Port of Barcelona, which is currently the number one Mediterranean port in terms of the number of cruise passengers. In quantitative terms, all these three points remained unaffected by the economic crisis.

\section{Literature and method}

Coastal and marine tourism in Mediterranean countries developed around the late 1950s, when tourists began to arrive from northern European countries, where income was on the rise with a new phase of prosperity that came along with the post-war period. Thus, we may be surprised by the observation of Bramwell (2004) on the lack of publications on the development, planning, and management of mass tourism in coastal areas. Urry (1990) drew attention to the particular feature of mass coastal tourism characterised by a labour market involving long periods of unemployment that alternate with briefer periods of long hours of intense work. King (1995) argues that despite tourism's contribution to the economy and to employment in many countries, the system for statistical study is still lacking, and is effectively an obstacle to the evaluation of the impact of tourism on employment and the effects of any restructuring of the supply of products and services. Montanari and Magnarapa (1998) point out that the statistical measurement of data on coastal tourism is inadequate for the transformations that the industry has undergone in recent decades. King (1995), referring to the work of the United Nations World Tourism Organization (UNWTO), identifies three sectors where tourism activity is concentrated. The most obvious is accommodation. Structures used exclusively by those that the UNWTO calls tourists are considered accommodation. However, this employment category also involves workers in restaurants, and other food and beverage structures. These businesses do not carry out functions exclusively for tourists as they are also used by residents and visitors.

Regional Statistics, Vol. 7. No. 2. 2017: 35-57; DOI: 10.15196/RS070204 
A second category is transport, although only in part as some lines and some services are directed at commuter users who travel repeatedly within metropolitan areas. A third category is tourism services, such as agencies, and information and marketing systems directed primarily towards tourists and in part towards visitors.

However, it must be noted that, as observed by Williams and Montanari (1995), the transition from Fordism to post-Fordism was neither linear nor universal. From the end of the 20 th century to today, mass tourism in Europe has co-existed with forms of tourism that are more individual and more attentive to unique cultural and environmental features.

The success of coastal and marine tourism in Mediterranean countries has its origins in the good level of economic development in Northern European countries, in the redistribution of income between the middle and lower classes, and finally, in paid holiday leave. To this end, we add the evolution of the air transport system, which has helped to reduce costs, as has tour operators' competitiveness in managing packages. Thus, the supply of tourism products and services has become ever more standardised, and competitiveness is increasingly based only on prices (Williams 1996). There were various motives for the local and national authorities to rush to develop the supply of mass coastal tourism products. According to Williams (2001), these motives are: 1. the regions of Southern Europe were economically and culturally behind in the 1960s and 1970s; 2 . tourism is considered as a tool of modernisation and cultural change, and political legitimisation and economic development; 3. tourism is also appreciated for being work-intensive and therefore a significant component in local development (Williams-Shaw 1988).

In the final decades of the $20^{\text {th }}$ century, coastal mass tourism began to show the first signs of crisis, and along with the hoped-for expectations and benefits, we began to observe the limits of uncontrolled development and destructive effects on the natural environment owing to the use of resources concentrated in a limited time and space (Bramwell 2004). The tourists who came from the north in the 1990s were already familiar with and practice of the principles of sustainable development, a concept still new in Mediterranean Europe. According to Bramwell (2004), the local tourism authorities interpreted this change in demand as a need for diversification of the product requiring investments on a larger scale, but primarily targeted to a clientele that would be willing to pay more. As such, golf courses, marinas for docking large boats, casinos, and congress centres were built. Essentially, mass tourism offers ever-decreasing profits, and those limited earnings fall into the hands of tour operators selling packages that include every possible product, leaving nothing, or almost nothing, for the local economy. Moussios (1999) reports that from 1995 to 1998, the Greek government approved investments for 13 congress centres, 5 marinas, 3 thalassotherapy centres, 2 golf courses, and $1 \mathrm{spa}$ centre. A second type of diversification involves the development of small-scale alternative tourism products based on enhancing and promoting tangi-

Regional Statistics, Vol. 7. No. 2. 2017: 35-57; DOI: 10.15196/RS070204 
ble and intangible cultural goods. Manente and Furlan (2004) report that in order to facilitate the expansion of the tourism season, and therefore for more efficient use of resources and production potential, it is necessary to modernise the product and to identify objectives separate from the current ones, in order to favour diversification of demand. The meaning of coastal tourism demand has changed completely 50 years later. The major operators are certainly aware of this. The cruise industry has also noticed this, and is offering a type of virtual coastal tourism that moves among the major Mediterranean ports, offering an easily modifiable and diversifiable quality product. The situation is more challenging for small companies, which struggle to deal with the rapid changes in demand, even with information and communication technologies (ICT) tools. Therefore, it is necessary to update all the parameters for identifying coastal and marine tourism. Hall (2001) argues that considering coastal and marine tourism, it is now necessary to indicate all the activities carried out on or near the coast that relate to tourism, leisure, and recreation These include accommodations such as hotels, second homes, restaurants, and cafes. We must then consider the services necessary for the activities involving the seaside, such as swimming, diving, boat trips, recreational fishing, and ecotourism practised on land and sea. Hall (2001) argues that marine tourism, closely tied to coastal tourism activities, also includes activities that must take place offshore, such as deep sea fishing and sailing on the open sea. With the development of technology that facilitated the use of vehicles on water and underwater, tourism has moved further into the open sea. Protected areas located in open waters can be an attraction for visitors as well as for study, and can therefore be economically supported by appropriate tourism activities. Montanari and Staniscia (2009) consider the coast to be part of a complex system made up of mountains, hills, coastal plains, open seas, and high seas.

Global climate change in recent decades has reduced the availability of resources in coastal areas; as such, there have been conflicts in the use of buildable land, beaches, and water (Montanari-Staniscia 2013). Khan et al. (2013) illustrate these conflicts and point out the sectors in which stakeholders with opposing interests concentrate their competing activities. Lohmann (2001) identifies three possible points of connections between tourism in coastal areas and the problems presented by global climate change: 1 . a climate change at the regional level; 2 . society's perception and assessment of climate change; political, administrative, and economic reactions; and 3. changing climatic conditions in areas with competing products. The issue is indeed complex and therefore challenging to manage; as such, it is fundamental that any solution involves policies that effectively involve all stakeholders (Montanari 2014).

Considering tourism purposes, mountain areas and hill areas can be used for walking, observing biodiversity, food and wine tourism, and cultural tourism. The coastal plains can be used for leisure, tourism, sports, play, swimming, eating

Regional Statistics, Vol. 7. No. 2. 2017: 35-57; DOI: 10.15196/RS070204 
meals, interpersonal relations, and people watching. The open sea offers swimming, recreational fishing, underwater observation, coastal sailing, windsurfing, parasailing, and water skiing. In the high seas, there are deep-sea fishing, diving, submarine tours, sailing and motor boating, and cruises (Montanari 2006). Montanari and Staniscia (2009) argue that there is a need for some rebalancing between overdeveloped coastal areas, and the nearby areas where an environment of quality still exists. Forms of tourism tied to an environment of good quality not only stimulate the economy, but also act as a form of protection for a fragile, at-risk area; this can be a contemporary form of sustainable development. Tourism is an area where various sectors overlap; accommodation and food and beverage make up for approximately half of the industry, and the rest is accounted by complementary activities and services, transport, rentals, travel agencies, business support services, and recreational, cultural, and sports activities. Data down to the level of municipalities on workers in the tourism sector have been extracted with the assistance of the relevant Istat offices. More specifically, companies were considered as tourism companies based on the following categories: 1. Lodging (purchase of real estate and real estate activities on behalf of third parties; rental and management of property owned or leased); 2. Food and beverage services; 3. Rail transport; 4. Water transport; 5. Other passenger land transport; 6. Air transport; 7. Rental and leasing activities; 8. Travel agency services, tour operators, and other booking services; 9. Creative, artistic, and entertainment activities; 10. Libraries, archives, museums, and other cultural activities; 11. Activities relating to lotteries, betting, gambling houses; 12. Sports, entertainment, and recreation.

At least one third of all European tourism businesses are concentrated in coastal areas. For a majority of small and medium-sized enterprises (SMEs), which have challenges solving the problems related to: 1 . seasonality of demand; 2 . material and immaterial accessibility of the places; 3 . environmental sustainability of supply; and 4. weight of taxation and of bureaucratic instruments management (Hotrec 2015). From the production point of view, the sector is very fragmented due to the role played by SMEs as participants and competitors propose (McCamley-Gilmore 2017). The quality of employment induced by tourism in the coastal areas is conditioned by the risk of advantages concentration in the hands of the large international tour operators to the detriment of local SMEs (Bramwell 2004). The tour operators, in-turn, locally use low-skilled labour, who are limitedly and badly paid. Issues faced by SMEs at the local level overlap with global competitiveness issues. A possible solution is identified in increasingly elaborate forms of public engagement by university research facilities (Page et al. 2017).

Regional Statistics, Vol. 7. No. 2. 2017: 35-57; DOI: 10.15196/RS070204 


\section{Coastal and marine tourism in Italy at the time of the crisis}

In Italy, coastal tourism developed according to the models of demand, which essentially meant the needs of citizens of Northern and Central Europe, where the economic crisis arrived earlier than in the countries of Mediterranean Europe. Coastal tourism developed in Europe beginning in the late 1700s, when European court culture and aristocratic families began to take an interest in the violent and inhospitable nature of the sea. The sea and coastal areas were also appreciated for their powers of healing all illnesses affecting the respiratory system. With industrialisation in Northern and Central Europe at the beginning of the $20^{\text {th }}$ century, the new middle classes tried to emulate the aristocratic model, developing a demand for coastal tourism that, while still elite, sought prices that were more standardised and therefore more affordable. Beginning after the end of World War II, the spread of paid holidays, and the greater distribution of income and welfare contributed to the democratisation of seaside tourism. The demand for summer holidays, due in part to increased industrial efficiency, found coastal tourism to be an increasingly efficient, low-cost product. Tour operators packaged a product that offered plenty of the aforementioned 'three S's, but was not connected to any specific holiday location. The number of tourists increased. In Southern Europe, their number exceeded the total capacity of the coastal areas (Montanari 1995). The 1970s' recession and the introduction of ICT tools contributed to changing who the tourists were, but not the numbers. Other consequences introduced the concept of 'sustainable tourism' into coastal tourism. The term was first defined in 1992 at the Earth Summit in Rio de Janeiro. However, the 'mass tourism' model for coastal tourism did not fail as a whole as the system was able to replace the less attractive sectors of what it supplied with new products, at prices that were even more competitive. Major investments in hotel and transportation infrastructure were made along the coasts of the Mediterranean as it was necessary to somehow protect these elements from the risk of total deterioration. At the beginning of the $21^{\text {st }}$ century, international terrorism began to have its effects on coastal tourism. This either occurred directly through attacks on foreign bathers in Tunisia or indirectly as the climate of uncertainty and risk discouraged tourists from the non-European countries of the Mediterranean. In the 2007-2015 period, the international economic crisis left tourists with less money to spend. Therefore, they chose products with a clearly defined price, such as cruises, or they chose more affordable locations. Terrorism and the economic crisis had converging effects, as both caused a concentration on European shores of tourists who had previously begun to show interest in other products and other areas, thus delaying the long-presaged downfall of the product.

Regional Statistics, Vol. 7. No. 2. 2017: 35-57; DOI: 10.15196/RS070204 
Therefore, data for 2001-2011, a period in which two crises - terrorism and the economic crisis - overlapped, reveal an increase in tourism, both in absolute and relative terms even if not homogeneously from region to region (see Figure 1). From Table 1, we can observe a significant difference in the distribution of the number of employees in the tourism sector across various regions of Italy. Essentially, approximately half of the workers are concentrated in only five regions, the same five regions where marginally more than half of the tourist overnights are concentrated. In 2001, in Trentino Alto Adige, there were 778 overnight stays for every worker in the tourism industry, and in Veneto, it was 480 overnights, while in Southern Italy, there were 230 overnight stays per worker in Calabria, and 200 in Sicily. This difference in the Southern regions is owing to the less efficient and seasonal tourism industry in the regions. In other cases, such as Piedmont with 101 overnight stays per worker, Lombardy with 124, and Latium with 187, the high number of employees is a result of the existence of large cities, where tourism services - except for accommodation - are also used by residents and commuters.

Figure 1

Percentage change in the number of tourism workers and tourist overnights by regions of Italy, 2001-2011

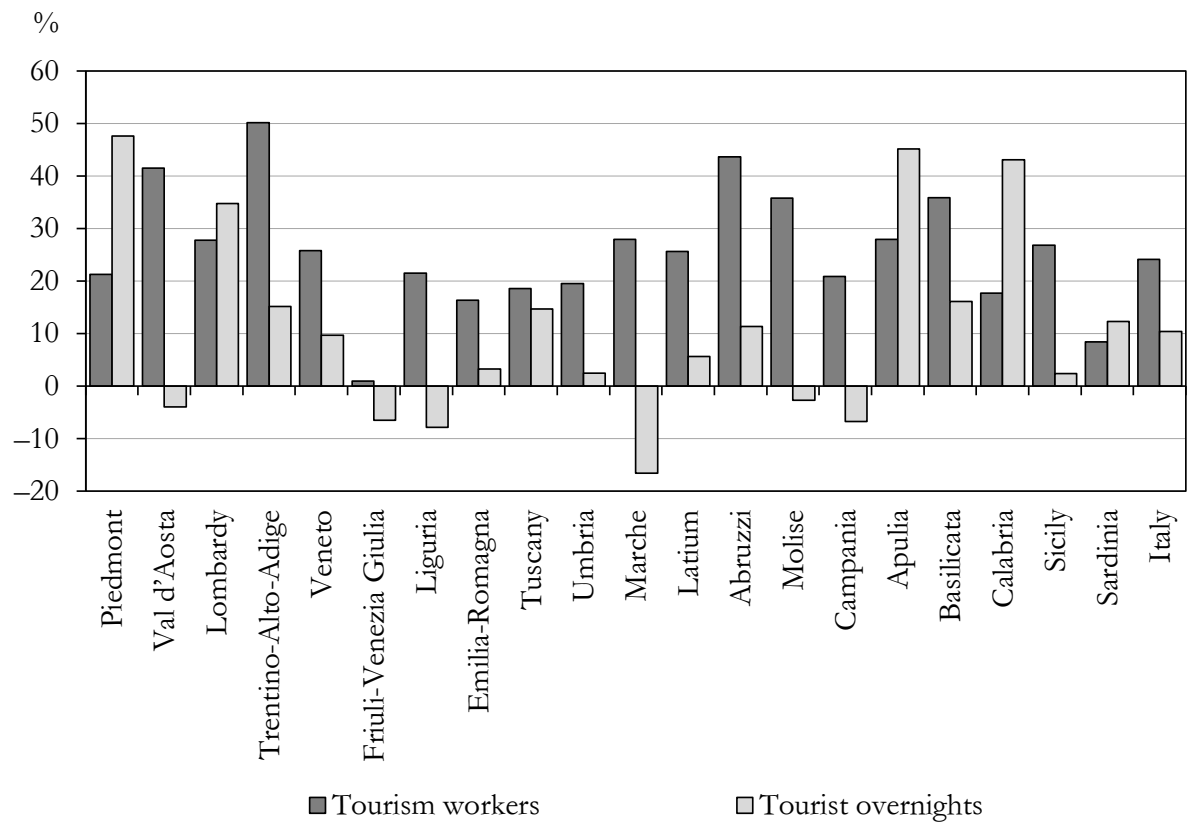

Source: Own elaboration based on Istat census reports for 2001 and 2011.

Regional Statistics, Vol. 7. No. 2. 2017: 35-57; DOI: 10.15196/RS070204 
Table 1

Number of tourism workers and tourist overnights by regions of Italy

\begin{tabular}{|c|c|c|c|c|c|c|}
\hline \multirow{3}{*}{ Region } & \multicolumn{2}{|c|}{ Tourism worker } & \multicolumn{2}{|c|}{ Tourist overnight } & \multicolumn{2}{|c|}{ Absolute change } \\
\hline & 2001 & 2011 & 2001 & 2011 & $\begin{array}{l}\text { Tourism } \\
\text { worker }\end{array}$ & $\begin{array}{c}\text { Tourist } \\
\text { overnight }\end{array}$ \\
\hline & \multicolumn{6}{|c|}{ thousand } \\
\hline Piedmont & 86.3 & 104.7 & $8,699.4$ & $12,845.1$ & 18.4 & $4,145.7$ \\
\hline Val d'Aosta & 7.5 & 10.6 & $3,254.4$ & $3,126.2$ & 3.1 & -128.2 \\
\hline Lombardy & 198.6 & 253.7 & $24,569.0$ & $33,123.6$ & 55.1 & $8,554.5$ \\
\hline Trentino-Alto-Adige & 49.3 & 74.1 & $38,350.6$ & $44,160.1$ & 24.7 & $5,809.5$ \\
\hline Veneto & 120.4 & 151.5 & $57,771.6$ & $63,401.3$ & 31.1 & $5,629.7$ \\
\hline Friuli-Venezia Giulia & 31.5 & 31.8 & $9,570.7$ & $8,949.6$ & 0.3 & -621.2 \\
\hline Liguria & 53.4 & 64.8 & $15,252.6$ & $14,060.6$ & 11.5 & $-1,191.9$ \\
\hline Emilia-Romagna & 114.0 & 132.7 & $37,406.8$ & $38,619.3$ & 18.7 & $1,212.6$ \\
\hline Tuscany & 103.3 & 122.5 & $38,089.8$ & $43,684.8$ & 19.2 & $5,595.0$ \\
\hline Umbria & 19.7 & 23.6 & $5,889.6$ & $6,037.0$ & 3.9 & 147.4 \\
\hline Marche & 31.2 & 40.0 & $13,210.0$ & $11,024.2$ & 8.7 & $-2,185.8$ \\
\hline Latium & 155.4 & 195.3 & $29,037.2$ & $30,681.0$ & 39.8 & $1,643.8$ \\
\hline Abruzzi & 24.4 & 35.1 & $6,666.3$ & $7,422.4$ & 10.7 & 756.2 \\
\hline Molise & 4.4 & 6.0 & 699.3 & 680.5 & 1.6 & -18.8 \\
\hline Campania & 87.3 & 105.5 & $20,962.6$ & $19,555.0$ & 18.2 & $-1,407.6$ \\
\hline Apulia & 49.7 & 63.7 & $9,304.3$ & $13,505.7$ & 13.9 & $4,201.4$ \\
\hline Basilicata & 8.0 & 10.9 & $1,690.4$ & $1,963.5$ & 2.9 & 273.1 \\
\hline Calabria & 26.0 & 30.6 & $5,974.6$ & $8,548.3$ & 4.6 & $2,573.7$ \\
\hline Sicily & 68.6 & 87.1 & $13,730.4$ & $14,057.9$ & 18.4 & 327.5 \\
\hline Sardinia & 36.4 & 39.5 & $10,193.5$ & $11,448.7$ & 3.1 & $1,255.2$ \\
\hline Italy (total) & $1,275.5$ & $1,583.5$ & $350,323.1$ & $386,894.7$ & 308.0 & $36,571.6$ \\
\hline
\end{tabular}

Note: Deviations from the total result from rounding.

Source: Own calculation based on Istat census reports for 2001 and 2011.

Italian tourist overnights decreased $(-7 \%)$, while foreign tourist overnights increased (14\%) during the 2000-2014 period (Becheri 2016). Tourism data in coastal areas are perhaps less reliable owing to the percentage of those not registered and as the percentage of second homes and visiting friends and relatives, is high. Becheri (2016) believes that the coastal tourism crisis is the result of a conjunctural, but also structural economic crisis. The sea tourism product needs a redefinition through its integration with many possible neighbourhood supplies. An intense debate has developed at an international level on the presence and evolution of second homes, their significance, and their social and economic impact (Hall-Müller 2004).

Regional Statistics, Vol. 7. No. 2. 2017: 35-57; DOI: 10.15196/RS070204 
The number of tourism workers per thousand residents is high only in the Northern and Central regions. There, with the exception of certain municipalities in the Po Valley, the number of tourism workers in relation to the population is high, both in the Alpine areas and in the Apennine hinterland. In the Southern regions, despite an equally beautiful landscape, and even more favourable climate and significant natural and cultural assets, the percentage of people who work in tourism is negligible, except small areas along the coast, particularly in Sardinia (see Figure 2a). Between 2001 and 2011, the values marginally changed throughout the country, but declined mainly in Sardinia and the other regions of the South (see Figure $2 \mathrm{~b}$ ). In 70\% of the 7,980 Italian municipalities, the numbers have remained stable or have dropped.

Figure 2a

Number of tourism workers per 1,000 residents by municipalities of Italy, 2011

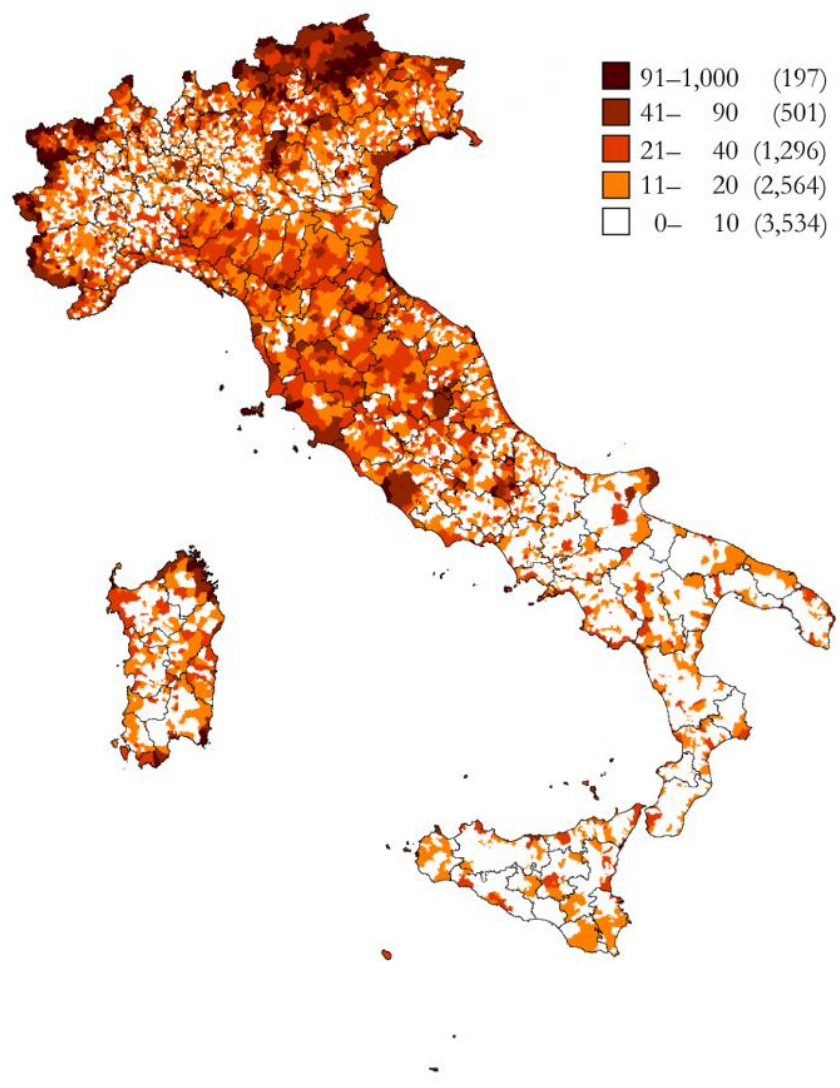

Note: The numbers of municipalities are indicated in brackets.

Source: Own elaboration based on Istat census reports for 2011.

Regional Statistics, Vol. 7. No. 2. 2017: 35-57; DOI: 10.15196/RS070204 
Figure 2b

Percentage change in the number of tourism workers by municipalities of Italy, 2001-2011

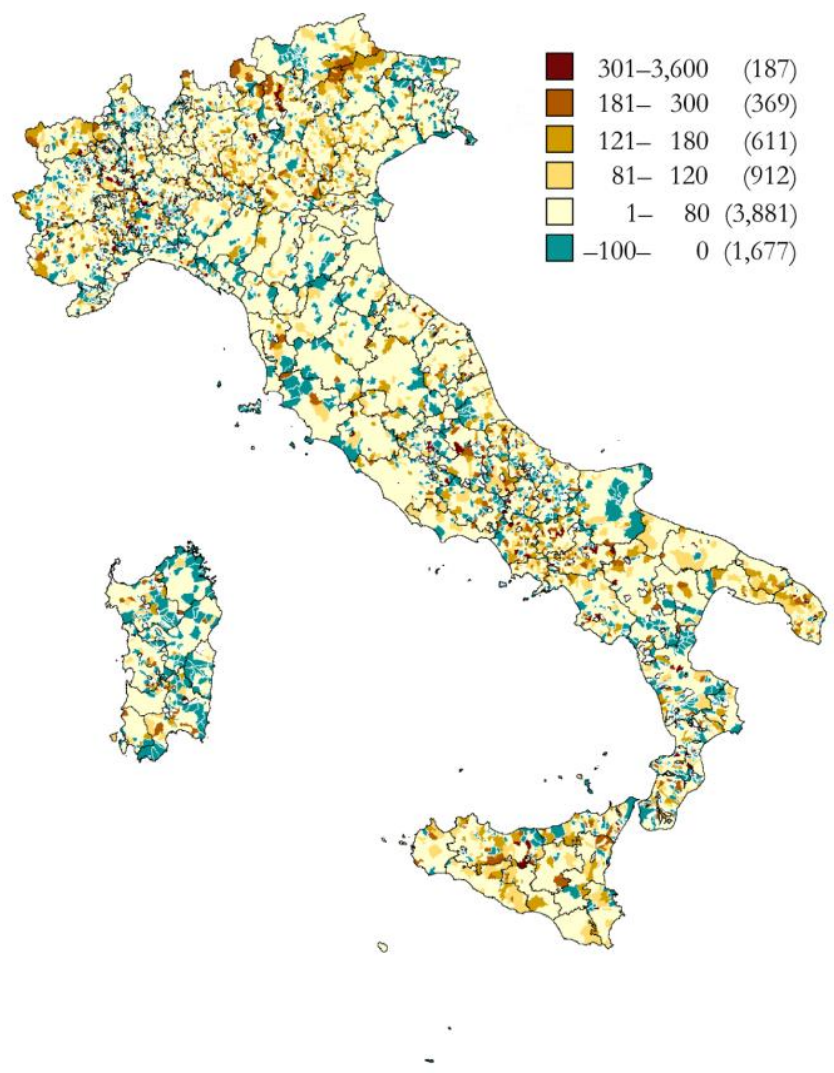

Note: The numbers of municipalities are indicated in brackets.

Source: Own elaboration based on Istat census reports for 2001 and 2011.

In 2001, coastal and marine tourism was creating significant employment numbers in relation to the number of residents in only $9 \%$ of the municipalities. These are municipalities that form a part of the nationally and internationally renowned tourism system, such as Veneto's Jesolo, Caorle, Lignano Sabbiadoro, and Grado; Emilia-Romagna's Bellaria, Rimini, and Riccione; and Tuscany's island of Elba (see Figure 3a). From 2001 to 2011, the trend was stable or negative for $76 \%$ of municipalities, while only $7 \%$ showed positive movement (see Figure 3b). Additional analysis has been conducted to find the rate of employees of small companies (those with fewer than 20 employees) per one thousand residents. We can observe employment in small businesses, in relation to the number of inhabitants in the Alps as well as in Central Italy in the inland area between the coast and peaks of the Apennines 
(see Figure 4a). Between 2001 and 2011, the figures for employment in small businesses were mostly negative. Only $5 \%$ of municipalities recorded a positive trend (see Figure 4b).

Number of coastal and marine tourism workers per 1,000 residents

Figure 3a by coastal municipalities of Italy, 2011

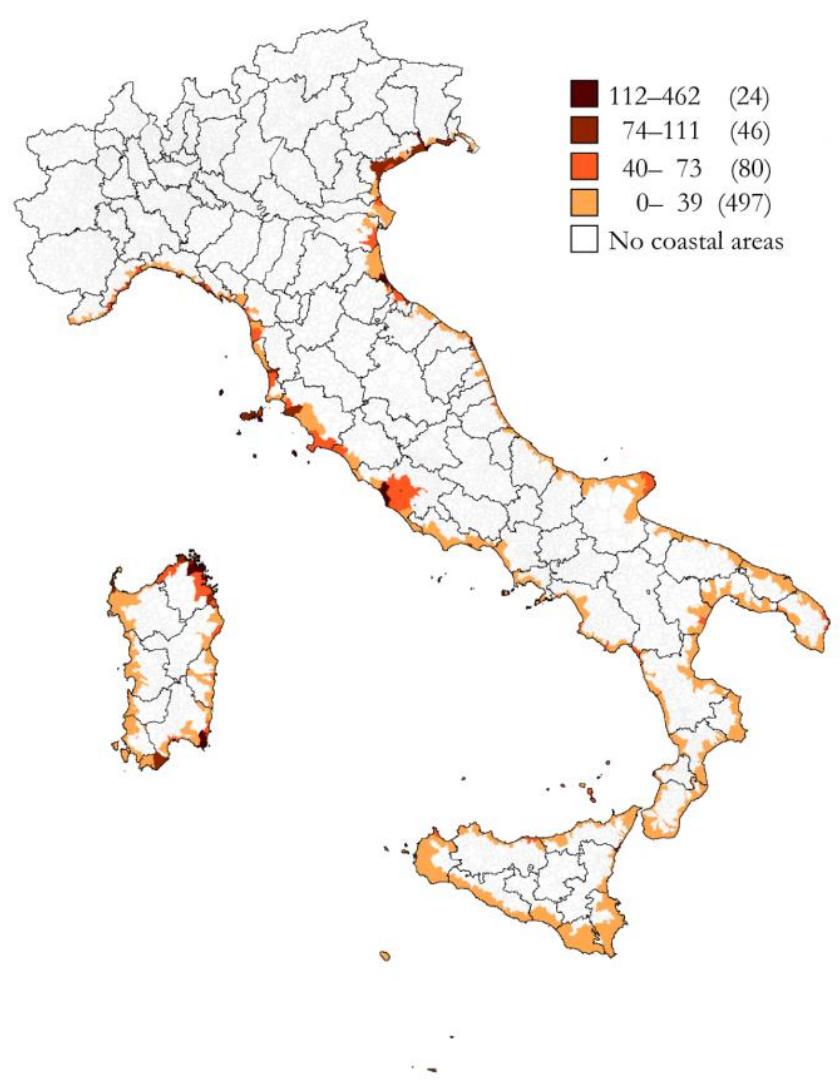

Note: The numbers of municipalities are indicated in brackets.

Source: Own elaboration based on Istat census reports for 2011.

Regional Statistics, Vol. 7. No. 2. 2017: 35-57; DOI: 10.15196/RS070204 
Figure 3b

Percentage change in the number of coastal and marine tourism workers by coastal municipalities of Italy, 2011-2001

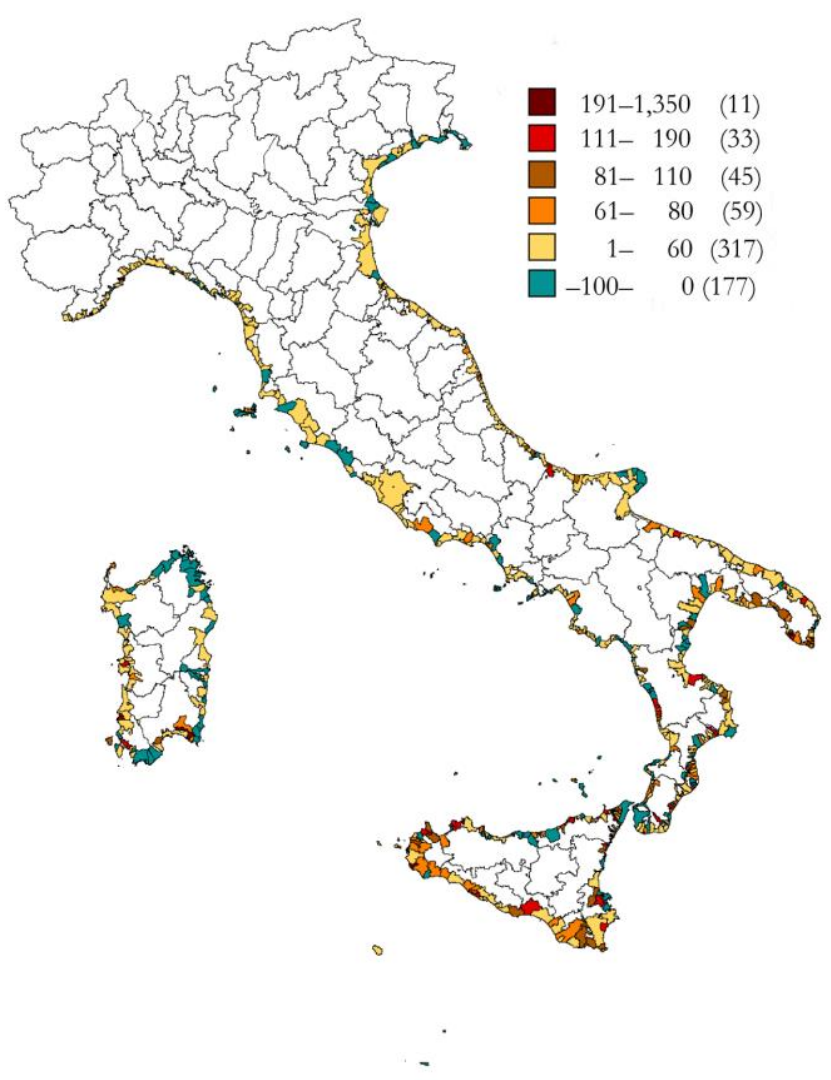

Note: The numbers of municipalities are indicated in brackets.

Source: Own elaboration based on Istat census reports for 2001 and 2011.

In the region of Latium, the relationship between tourism workers and residents in the municipality shows that tourism's contribution is mainly concentrated in a small number of municipalities that account for $14 \%$ of the region total (see Figure 4a). These most significant values are concentrated around mountain tourism, historic towns in the hilly areas, and spa areas. Tourism activity is more important in the area of coastline north of Rome. The changes seen during the 2001-2011 period are predominantly negative. $80 \%$ of Latium's municipalities recorded no change or even negative change. All the municipalities on Latium's coast saw a drop in tourism employment in relation to the resident population (see Figure 4b). 
Number of tourism workers employed by SMEs per 1,000 residents, by municipalities of Italy, 2011

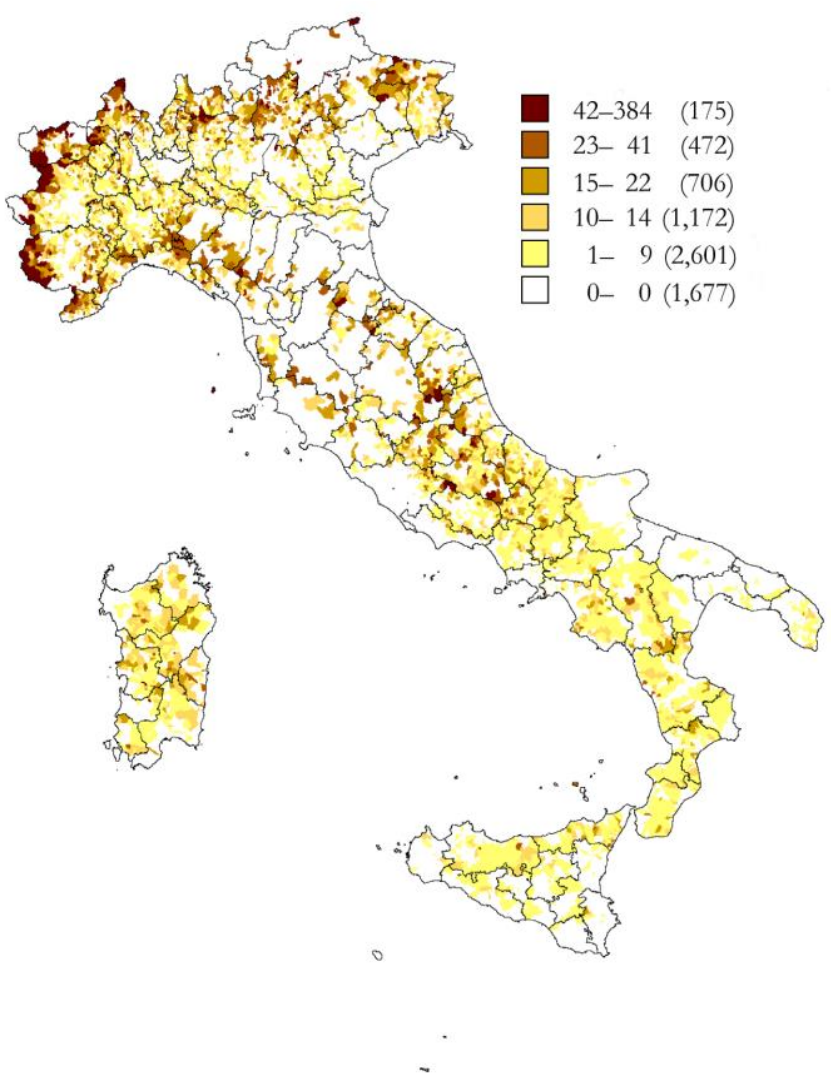

Note: SMEs have less than 20 employees. The numbers of municipalities are indicated in brackets. Source: Own elaboration based on Istat census reports for 2011. 
Percentage change in the number of tourism workers employed by SMEs,

Figure $4 b$ by municipalities of Italy, 2001-2011

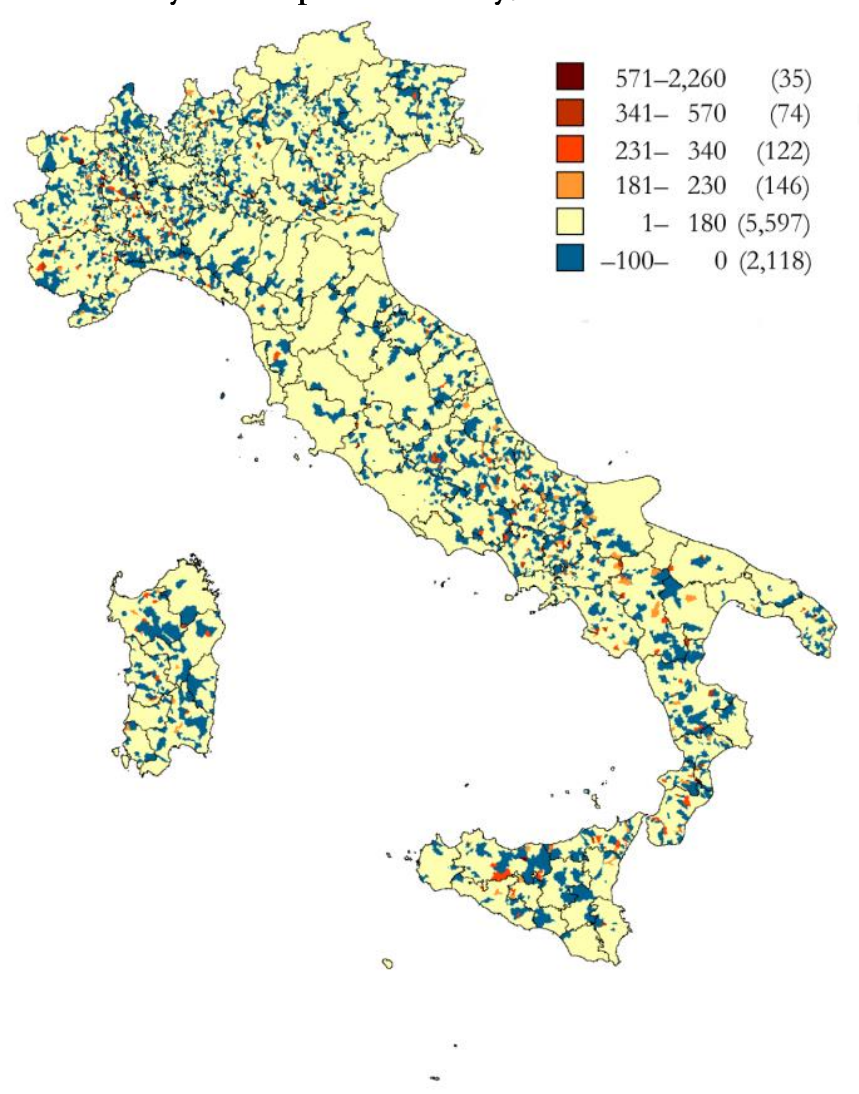

Note: SMEs have less than 20 employees. The numbers of municipalities are indicated in brackets. Source: Own elaboration based on Istat census reports for 2001 and 2011.

The locations of SMEs show three main areas: 1 . coastal zones where the presence of workers in relation to the resident population is irrelevant; 2 . low hilly areas where only a few municipalities show a significant percentage of workers; 3 . higher hilly areas where municipalities have a higher percentage of workers (see Figure 5a). A comparison between 2001 and 2011 data reveals a decrease in the percentage of employees in small businesses in most of Latium's municipalities (see Figure 5b). 
Figure $5 \mathrm{a}$

Number of tourism workers per 1,000 residents by municipalities of Latium, 2011

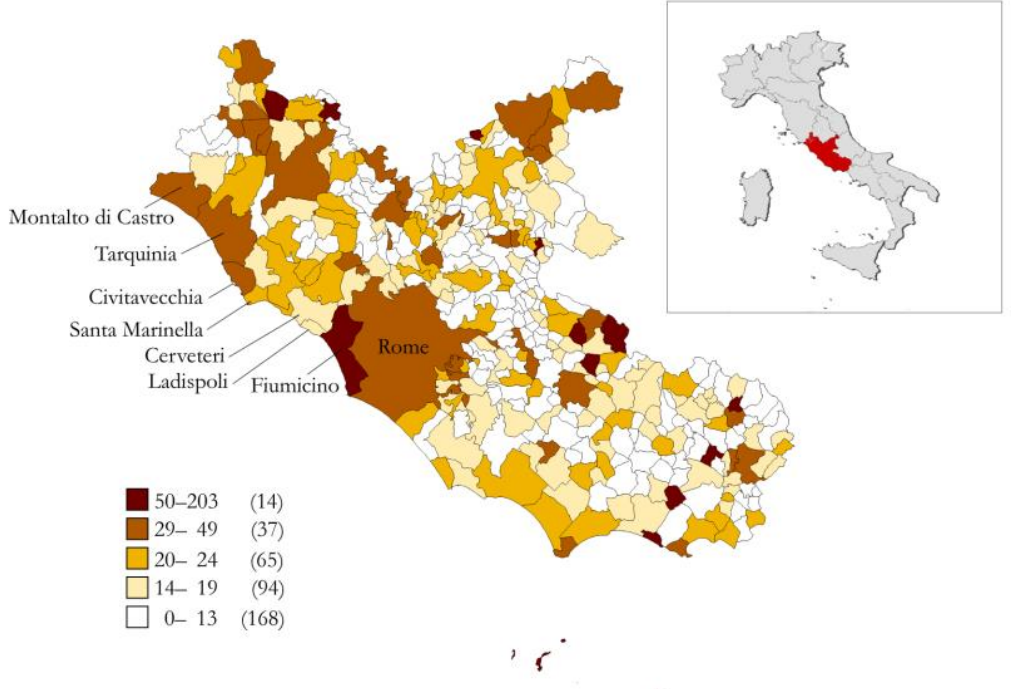

Note: The numbers of municipalities are indicated in brackets.

Source: Own elaboration based on Istat census reports for 2001 and 2011.

Figure 5b

Percentage change in the number of tourism workers by municipalities of Latium, 2011-2001

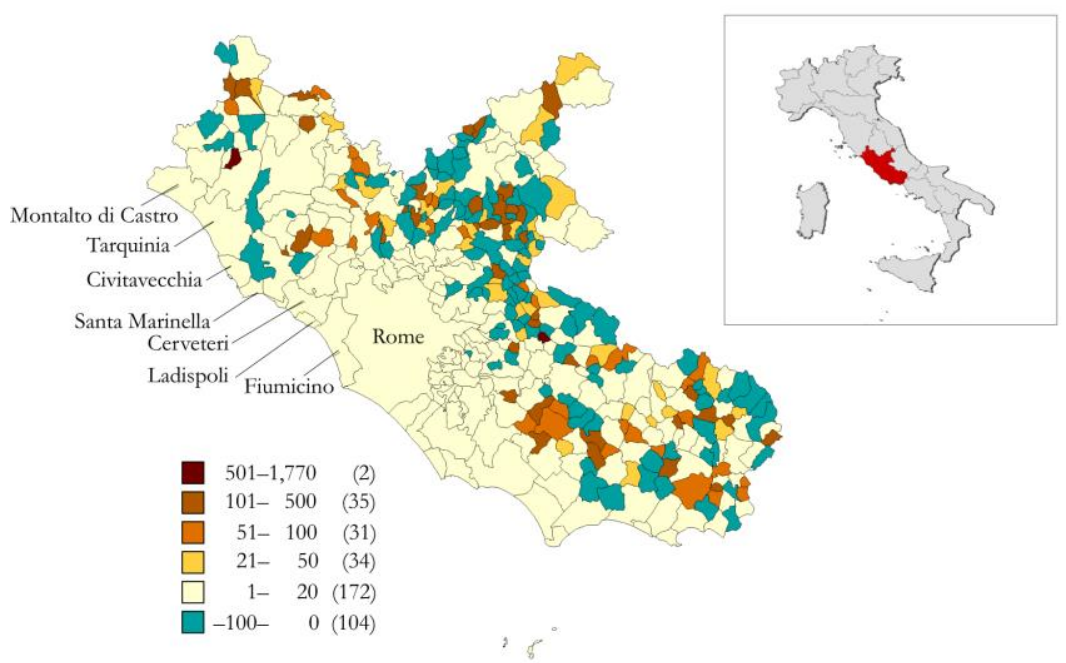

Note: The numbers of municipalities are indicated in brackets.

Source: Own elaboration based on Istat census reports for 2001 and 2011.

Regional Statistics, Vol. 7. No. 2. 2017: 35-57; DOI: 10.15196/RS070204 
The coastal area of northern Latium between Rome and the municipality of Montalto di Castro on the border of Tuscany has been selected as it is currently experiencing a dip in economic activity, and therefore presents potential for a new phase of regional development, particularly in relation to the three aforementioned transit points of Italian and international tourism. Approximately 42 million passengers travelled through Fiumicino Leonardo da Vinci airport in 2016. That same year, more than 2 million travellers came through the port of Civitavecchia via cruises, as well as merely under 2 million in transited to Sardinia. In Rome, in 2015, approximately 25,000 stays in accommodations were reported. Altogether, approximately 72 million Italians and foreigners passed through the area. It is striking to note that there has not yet been success in creating the conditions to bring even a small percentage of passengers into the area to transform them from people in transit to visitors and tourists. After the end of the World War II, the northern coastal area was occupied mainly by second homes. The owners of these houses resided in Rome and went to spend their summer holidays in seaside resorts. From the 1970s and 1980s onwards, there has been a gradual trend towards renting these houses in the winter months. Between the end of the 1990s and the early years of this century, the second homes were rented throughout the year to the immigrant communities that worked in Rome (Montanari-Staniscia 2011).

The only urban area north of Rome organised for permanent residence was Civitavecchia. The realisation of transportation infrastructure, including the RomaCivitavecchia motorway and the opening of the Cerveteri-Ladispoli stop on the Roma-Genova railway line laid the foundations for turning second homes into primary homes. This transformation accelerated during the years of the economic crisis, as the cost of housing and the cost of living in general were lower in the coastal areas outside Rome than in the central areas of Rome (Montanari-Staniscia 2011). Considering the same economic reason, many communities of immigrants settled in the municipalities along the coast. The largest is in the municipality of Ladispoli, with approximately $18.5 \%$ of the population. The largest foreign community is from Romania, followed by those from Poland and India. The next are Montalto di Castro (13.2\%), Fiumicino (12.2\%), Santa Marinella (10.2\%), Cerveteri $(8.9 \%)$, Tarquinia $(5.2 \%)$, and Civitavecchia $(5.0 \%)$. Most area companies are not offering services for tourists but only for users with the second homes. There are relatively few lodging facilities for tourists. Near the coast, there are numerous farms, and there is a brisk fishing industry in the sea just beyond the coast. These activities do not involve any product integration and coordination, thus there are no guidelines to follow for any type of marketing. It is also a territory rich in cultural heritage, layered with the history of the Etruscan civilisation, the Roman Empire, and artefacts from middle ages. These are important findings, but the area's cultural resources are not given sufficient attention and value. Before the recent developments, the coast offered a natural environment of great value; only scraps that remain now need to be restored in order to reintroduce the continuity of the original

Regional Statistics, Vol. 7. No. 2. 2017: 35-57; DOI: 10.15196/RS070204 
ecosystem. The changes from 2001 to 2011 for the main types of tour operators have been analysed for the seven municipalities in the area as well as for Rome. In Table 2, we have shown the types with negative change.

Table 2

Number of the resident population and various tourism workers in the northern coastal municipalities of Latium and absolute change in their number

\begin{tabular}{|c|c|c|c|c|c|c|c|c|}
\hline \multirow{2}{*}{$\begin{array}{l}\text { Number of the resi- } \\
\text { dent popula- } \\
\text { tion/tourism workers } \\
\text { and absolute change in } \\
\text { their number }\end{array}$} & \multicolumn{7}{|c|}{ Municipality } & \multirow[b]{2}{*}{ Rome } \\
\hline & $\begin{array}{l}\text { Montalto } \\
\text { di Castro }\end{array}$ & Tarquinia & $\begin{array}{c}\text { Civitavec- } \\
\text { chia }\end{array}$ & $\begin{array}{c}\text { Santa } \\
\text { Marinella }\end{array}$ & Cerveteri & Ladispoli & Fiumicino & \\
\hline $\begin{array}{l}\text { Resident population, } \\
2011\end{array}$ & 8,770 & 16,016 & 51,229 & 17,403 & 35,207 & 37,293 & 67,626 & $2,617,175$ \\
\hline $\begin{array}{l}\text { Absolute change, } \\
\text { 2011-2001 }\end{array}$ & 1,117 & 854 & 1,197 & 2,452 & 8,435 & 7,325 & 17,091 & 70,371 \\
\hline $\begin{array}{l}\text { Tourism sector oper- } \\
\text { ators (total), } 2011\end{array}$ & 343 & 473 & 1,452 & 348 & 642 & 554 & 13,685 & 127,109 \\
\hline $\begin{array}{l}\text { Absolute change } \\
\text { (total), 2011-2001 }\end{array}$ & -1 & -31 & 138 & -62 & 230 & 107 & 4,965 & 20,511 \\
\hline $\begin{array}{l}\text { Hotel and hospitality } \\
\text { sector operators, } \\
2011\end{array}$ & 52 & 33 & 75 & 40 & 5 & 52 & 435 & 16,084 \\
\hline $\begin{array}{l}\text { Absolute change, } \\
\text { 2011-2001 }\end{array}$ & 1 & -46 & 1 & -84 & 3 & -29 & 8 & 10,140 \\
\hline $\begin{array}{l}\text { Catering and food } \\
\text { service sector opera- } \\
\text { tors, } 2011\end{array}$ & 173 & 325 & 945 & 240 & 391 & 392 & 2,273 & 49,899 \\
\hline $\begin{array}{l}\text { Absolute change, } \\
\text { 2011-2001 }\end{array}$ & 34 & 33 & 390 & 36 & 146 & 151 & 824 & 17,441 \\
\hline $\begin{array}{l}\text { Passenger transport, } \\
\text { and hiring, renting or } \\
\text { leasing sector opera- } \\
\text { tors, } 2011\end{array}$ & 35 & 33 & 260 & 4 & 181 & 30 & 10,777 & 35,133 \\
\hline $\begin{array}{l}\text { Absolute change, } \\
\text { 2011-2001 }\end{array}$ & 7 & -2 & -298 & -6 & 52 & -5 & 4,052 & $-1,100$ \\
\hline $\begin{array}{l}\text { Museum sector and } \\
\text { other cultural exhibi- } \\
\text { tion operators, } 2011\end{array}$ & 76 & 68 & 68 & 54 & 45 & 68 & 137 & 20,321 \\
\hline $\begin{array}{l}\text { Absolute change, } \\
\text { 2011-2001 }\end{array}$ & -50 & -16 & -25 & -14 & 15 & -19 & 27 & 2,921 \\
\hline $\begin{array}{l}\text { Travel agency sector } \\
\text { and tour operators, } \\
2011\end{array}$ & 7 & 14 & 104 & 10 & 20 & 12 & 63 & 5,672 \\
\hline $\begin{array}{l}\text { Absolute change, } \\
\text { 2011-2001 }\end{array}$ & 7 & - & 70 & 6 & 14 & 9 & 54 & 235 \\
\hline
\end{tabular}

Source: Own calculation based on Istat census reports for 2001 and 2011. 
The entire category of cultural activities for tourism and recreation is negative. The passenger transport sector is also negative, though it has certainly increased since the beginning of the century for cruise operations out of Civitavecchia. Some companies also use Civitavecchia as a departure port for cruise ships. Cruise passengers arrive at Fiumicino Airport and then go to Civitavecchia, or take taxis to Rome while the ship is stopped in the harbour. In the future, rental cars could bring cruise passengers to visit the coast's cultural and natural resources. Rather, it appears that these activities are drawing visitors to the municipalities away from the coast. Exploitation of the coast has also contributed to erosion. This would best be addressed by protecting and restoring the surviving shore areas that have already been identified by the European Commission, but have not yet been offered protection by the Italian authorities. The way in which coastal and seaside tourism has been packaged no longer corresponds to the demand. Indications that the product is failing can already be seen, though the effects have been dampened by the increase in Italian users who have turned their backs on non-EU Mediterranean countries for safety reasons. The problem can be addressed and solved by integrating various types of tourist products and services offered in a horizontal network. The various independent sectors could draw-up agreements for collaboration to offer a structured product on Latium's northern coast involving all the participating companies. The network of companies will be able to offer a greater wealth of products and services, overcome the low visibility of small companies, and strengthen their ability to negotiate with global players, such as tour operators, airlines, and cruise lines.

\section{Conclusions}

The global economic crisis created numerous problems for all production sectors. To verify the effects of the crisis on tourism companies, we have examined the number of employees between 2001 and 2011, the years for which sufficiently detailed, analogous data are available. In any case, we know that Italian entrepreneurs in the tourism industry have been trying to handle the crisis by cutting down on fixed-term jobs and diversifying the activities of the most experienced and specialised workers who could be essential during the period of economic recovery. Therefore, the crisis has weighed on employment significantly more than the official statistics are able to show. The recent crisis, similar to previous ones, has however allowed us to reflect on the changes in the market and on how the product supplied should be reformulated. Besides these changes, there is also the doubt and controversy caused by the European Directive 2006/123/EC, also known as the Bolkestein Directive, which allows all European citizens to start a business on public land in any EU country. The problem is particularly experienced in in coastal areas, as all of Italy's beaches are the property of the state. All these problems can

Regional Statistics, Vol. 7. No. 2. 2017: 35-57; DOI: 10.15196/RS070204 
be solved by more (environmentally) appropriate use of coastal areas, by promoting a product that is new in integrating with the territory offering it, and by establishing horizontal cooperation between all the tourism professionals, all offering in their own way a variety of material and immaterial cultural assets that represent the territory well.

\section{REFERENCES}

BECHERI, E. (2016) I turismi del mare: le vacanze balneari In: BECHERI, E. -MAGGIORE, G. (eds.) XX Rapporto sul Turismo Italiano pp. 437-460., Rogiosi, Napoli.

Bramwell, B. (2004) Mass Tourism, Diversification and Sustainability in Southern Europe's Coastal Region In: Bramwell, B. (ed.) Coastal Mass Tourism. Diversification and Sustainable Development in Southern Europe pp. 1-31., Channel View Publications, Clevedon.

Claval, P. (1995) The Impact of Tourism on the Restructuring of European Space In: Montanari, A.-Williams, A. M. (eds.) European tourism: Regions, Spaces and Restructuring pp. 247-262., Wiley, Chichester.

DWYER, L.-FORSYTH, P. (1998): Economic Significance of Cruise Tourism Annals of Tourism Research 25 (2): 393-415. https://doi.org/10.1016/S0160-7383(97)00098-4

HALL, C. M. (2001): Trends in ocean and coastal tourism: the end of last frontier? Ocean and Coastal Management 44 (9-10): 601-618. https://doi.org/10.1016/S09645691(01)00071-0

HALl, C. M.-MÜLLER, D. K. (2004): Introduction: Second Homes, Curse or Blessing? Revisited. In: Hall, C. M.-Müller, D. K. (eds.) Tourism, Mobility and Second Homes. Between Eliter Landscape and Common Ground pp. 3-14., Channel View, Clevedon.

Hotrec, Hospitality Europe (2015): Position paper on "A European strategy for more growth and jobs in coastal and maritime tourism", adopted by Hotrec General Assembly on 17 April 2015, Brussels.

KHAN A. Z.-QUYNH, L. X.-CORIJN, E.-CANTERS, F. (eds.) (2013): Sustainability in the Coastal Urban Environment: Thematic Profiles of Resources and Their Users Sapienza Università Editrice, Roma.

KING, R. (1995): Tourism, Labour and International Migration in Europe In: MONTANARI, A.-.Williams, A. M. (eds.) European Tourism: Regions, Spaces and Restructuring pp. 177-190., Wiley, Chichester.

Lohmann, M. (2001) Coastal Resorts and Climate Change In: LOCKWOOD, A.-MEdLIK, S. (eds.) Tourism and Hospitality in the $21^{\text {st }}$ Century pp. 284-295., Butterworth, Oxford.

Manente, M.-Furlan, M. C. (2004) Seasons and tourist products in the coastal destinantions: the case of Jesolo In: WeBER, S.-TOMLJENOVIĆ, R. (eds.) Reinventing a Tourism Destination - Facing the Challenge pp. 191-203., Institute for Tourism, Zagreb.

Marchena Gómez, M. J.-Vera Rebollo, F. (1995) Coastal areas: processes, typologies and prospects In: Montanari, A.-Williams, A. M. (eds.) European Tourism. Regions, Spaces and Restructuring pp. 111-126., Willey, Chichester.

Regional Statistics, Vol. 7. No. 2. 2017: 35-57; DOI: 10.15196/RS070204 
McCamley, C.-Gilmore, A. (2017): Aggravated fragmentation: a case study of SME behaviour in two emerging heritage tourism regions Tourism Management 60: 8191. https://doi.org/10.1016/j.tourman.2016.11.016

Montanari, A. (1995): The Mediterranean Region: Europe's Summer Leisure Space In: Montanari, A.-Williams, A. M. (eds.) European Tourism. Regions, Spaces and Restructuring pp. 41-65., Willey, Chichester.

MONTANARI, A. (2006): Il turismo abruzzese come strumento di integrazione e riequilibrio del territorio attraverso l'utilizzo delle risorse locali. Il ruolo dell'ecoturismo e del turismo enogastronomico In: BuZZETTI, L.-Montanari, A. (eds.) Nuovi scenari turistici per le aree montane. Abruzzo e Trentino: sviluppo locale e competitività del territorio pp. 81-122., Valentina Trentini, Trento.

Montanari, A. (ed.) (2014): Mitigating Conflicts in Coastal Areas through Science Dissemination. Fostering Dialogue between Researchers and Stakeholders Sapienza Università Editrice, Roma.

MONTANARI, A.-MAGNARAPA, C. (1998): The geography of marine tourism and recreation In: BuzzetTI, L. ET AL. (eds.) Italy's Sea. Problems and perspectives pp.167187., Società Geografica Italiana, Roma.

MOntanARI, A.-STAniscia, B. (2009): Culinary tourism as a Tool for Regional Reequilibrium European Planning Studies 17 (10): 1463-1483. https://doi.org $/ 10.1080 / 09654310903141656$

MontAnARI, A.-STAniscia, B. (2011): From global to local: Human mobility in the Rome coastal area in the context of the global economic crisis BELGEO, Belgian Journal of Geography 12 (3-4): 187-200. https://doi.org/10.4000/belgeo.6300

Montanari, A.-STAniscia, B. (2013): Global Changes, Coastal Areas and Conflicts: Experiences from Italy In: KHAN, A. Z.-QUYNH, L. X.-CANTERS, F.-CORIJN, E. (eds.) Environmental Conflicts in Coastal Urban Areas: Towards a Strategic Assessment Framework for Sustainable Development pp. 100-136., Sapienza Università Editrice, Roma.

Moussios, G. (1999): Greece Country Report Travel and Tourism Intelligence 2: 24-49.

Page, S. J.-HARTWELl, H.-Fyald, J.-Hemingway, L. (2017): Case study: wellness, tourism and small business development in a UK coastal resort: public engagement in practice Tourism Management 60: 466-477. https://doi.org/10.1016/j.tourman. 2016.12.014

Urry, J. (1990): The Tourist Gaze: Leisure and Travel in Contemporary Societies, SAGE, London.

Williams, A. M. (1996): Mass tourism and international tour companies In: BARKE, M.Towner, J.-NewTon, M. T. (eds.) Tourism in Spain: Critical Issues pp. 119135., CAB International, Wallingford.

Williams, A. M.(2001): Tourism and Development in the Mediterranean Basin: evolution and Differentiation on the "Fabled Shore" In: KING, R.- DE MAS, P.Mansvelt BeCK, J. (eds.) Geography, Environment and Development in the Mediterranean pp. 156-175., Sussex Academic Press, Brighton.

Regional Statistics, Vol. 7. No. 2. 2017: 35-57; DOI: 10.15196/RS070204 
Williams, A. M.-MONTANARI, A. (1995): Introduction: tourism and restructuring in Europe In: Montanari, A.-Williams, A. M. (eds.) European Tourism: Regions, Spaces and Restructuring pp.1-16., Wiley, Chichester.

Williams, A. M.-SHAW, G. (1988): Tourism: candyfloss industry or job generators Town Planning Review 59 (2): 81-104. https://doi.org/10.3828/tpr.59.1.2r72w70p 330v61v0

Regional Statistics, Vol. 7. No. 2. 2017: 35-57; DOI: 10.15196/RS070204 